\title{
Yetişkin Eğitimi Analiz Ölçeği Kursiyer Formunun Geliştirilmesi ve Kursiyer Görüşlerinin Çeşitli Değişkenler Açısından İncelenmesi ${ }^{1}$
}

\author{
DOI: $10.26466 /$ opus.901823
}

\author{
Engin Dilbaz * - Coşkun Bayrak ** \\ * Dr., Milli Eğitim Bakanlığı, Eskişehir İl Milli Eğitim Müdürlüğü, Eskişehir/Türkiye \\ E-Posta: engin dilbaz@anadolu.edu.tr \\ ORCID: 0000-0001-9382-9691 \\ ** Prof. Dr., Anadolu Üniversitesi, Eğitim Fakültesi, Eskişehir/Türkiye \\ E-Posta: cbayrak@anadolu.edu.tr \\ ORCID: $\underline{0000-0001-5524-5206}$
}

Öz

\begin{abstract}
Araştırmanın amacı Türkiye'de yetişkin eğitiminin politik ve stratejik özelliklerini, örgütsel yapısını ve uygulamaların kursiyer görüşlerine göre analiz etmeye yönelik Yetişkin Ĕ̆itimi Analiz Ölçeği Kursiyer Formu'nu geliştirmek ve kursiyerlerin görüşlerine göre yetişkin eğitimini çeşitli değgişkenler açısından incelemektir. Araştırmanın birinci aşamasında Yetişkin Eğitimi Analiz Ölçeği Kursiyer Formu geliştirilmiştir. Bu aşamada kolay ulaşılabilirlik yoluyla seçilen 397 kursiyer ile çalışılmıştır. Analizler sonucunda toplam varyansin \%47,32'sini açıklayan, 17 maddeli ve öz değerleri 1.00'in üzerinde olan 3 faktörlü bir yapı ortaya konmuştur. Araştırmanın ikinci aşaması betimsel tarama modelinde tasarlanmıştır. İkinci aşamada tabakalı örnekleme yoluyla seçilen 614 katılımcı araştırmanın örneklemini oluşturmaktadır. Bu aşamada verilerin analizinde çoklu regresyon analizi (MANO$V A)$ ve t-test kullanılmıştır. Kursiyerlerin görüşlerinin çeşitli değişkenler açısından incelenmesi amacıyla yapılan çalışma sonucunda katılımcıların 37,4 oran ile en çok lise mezunlarından oluştuğu; katıldıkları kurs sayısı arttıkça kursiyerlerin, eğitim uygulamalarının niteliğine iliş̧kin görüşleri negatif yönde değişkenlik gösterdiği sonuçlarına ulaşılmıştır. Sonuç olarak; araştırmanın farklı evrenlerde tekrar yapılarak sonuçlarının karşılaştırılması önerilmektedir.
\end{abstract}

Anahtar Kelimeler: Ölçek, Örgütsel Yapı, Politika Ve Strateji, Yetişkin Eğitimi.

\footnotetext{
${ }^{1}$ Bu makale 14/01/2021 tarihinde Anadolu Üniversitesi Eğitim Bilimleri Anabilim Dalı'nda doktora tezi olarak kabul edilen "Türkiye'de Yetişkin Eğitimi Politikaları ve Kavramsal bir Model Önerisi" başlıklı çalışmadan türetilmiştir.
} 


\title{
Development of Adult Education Analysis Scale Trainee Form and Examining Trainee Views in Terms of Various Variables ${ }^{2}$
}

\begin{abstract}
The aim of the research is to develop the Adult Education Analysis Scale Trainees Form analyzing political and strategic characteristics, organizational structure and practices of adult education in Turkey according to the views of trainees, and to analyze the adult education according to the views of trainees in terms of different variables. In the first phase of the study, the Adult Education Analysis Scale Trainee Form was developed. In this phase, 397 trainees selected through easy accessibility were studied. As a result of the analysis; a 3-factor structure with 17 items and eigenvalues above 1.00, which explains $47.32 \%$ of the total variance, was revealed. The second stage of the research is designed in descriptive scanning model. In the second stage, 614 participants selected through stratified sampling form the sample of the study. At this stage, multiple regression analysis (MANOVA) and t-test were used to analyze the data. As a result of the study conducted in order to examine the views of the trainees in terms of various variables, it was concluded that the participants were mostly high school graduates with 37.4 percent; and as the number of courses they attended increase, the views of the trainees on the quality of their training practices change negatively. As a result; it is recommended to repeat the research in different universes and compare the results.
\end{abstract}

Keywords: Scale, Organizational Structure, Policy and Strategy, Adult Education.

\footnotetext{
${ }^{2}$ This article is derived from the study titled "Adult Education Policies in Turkey and A Conceptual Model Proposal", which was accepted as a doctoral thesis in Anadolu University Educational Sciences Department on 14/01/2021.
} 


\section{Giriş}

Eğitim, sosyal formların değişimlere uyum sağlayarak kendilerini geliştirebilmelerine olanak sağlayan önemli bir araçtır. Bir bakıma eğitim, toplumların geleceğe ilişkin bir hazırlığı olarak da nitelendirilebilir. Bu bağlamda politika yapıcı ve karar alıcı mekanizmalar, sürekli değişimin sunduğu yeni bakış açları ve yöntemler izleğinde eğitim politikaları tasarlamak ve mevcut politikalarını sürekli olarak geleceğe hazırlamak durumundadırlar.

Küreselleşme izleğinde yirmi birinci yüzyılın gerektirdiği yeni birey tipi giderek çeşitlenen becerilerle ve yeterlik alanlarıyla karşı karşıyadır. Bu bağlamda, yetişkin bireyleri yeni öğrenme, beceri ve yeterlik alanlarına hazırlamak; bunun yanı sıra var olan beceri ve yeterliliklerini geliştirmek de yetişkin eğitimi (YE) alanından beklenen bir görevdir.

Becerilerin ve bilginin hızla güncelliğini yitirdiği dünyada hangi seviyede olursa olsun YE faaliyetlerinden herkesin faydalanarak kendini geliştirmesine gereksinim bulunmaktadır. Bu bağlamda tarihsel süreç içerisinde YE hem kişilerin hem de toplumların gelecekleri açısından dikkate değer eğitsel faaliyet alanlarından biri haline gelmiştir (Miser, 2002, s.56). YE'deki ana amaç ülkelerin ve toplumların sorunlarının çözülebilmesi için yetişkinlerin eğitilmesidir (Park, 2002, s.286). Bununla birlikte bireyler; yaşamları süresince elde etmiş olduklan değerleri, becerileri, bilgileri ve anlayışları geliştirmektedirler. Bütün bunları gerçek hayatlarında kullanmalarına olanak veren sürecin ise hayat boyu (yaşam boyu) öğrenme olduğu ifade edilebilir (Candy, 2003). Hayat boyu öğrenme, örgün eğitime bir alternatif olmanın ötesinde zorunlu eğitim döneminde eksik kalan veya yetersiz görünen bilgilerin yetişkinler tarafından sonraki zamanlarda istendik şekilde elde edilmeye çalışılması süreci şeklinde de ifade edilebilir (Oktay, 2001).

Eğitim olgusu okul kavramıla sinırlanamamaktadır. Bununla birlikte yaşam boyu devamlılık gösteren öğrenme gereksiniminin giderilmesi adına toplumdaki yetişkin bireylere erişilmeye çalışılmakta ve bu bireylere bilgiyi aktarmanın yöntemleri aranmaktadır. Bilgi toplumları içerisinde eğitim sistemi, okul kavramıla sınırlı olmayıp, ileri seviyeden eğitim almış bireylerin dahi eğitimlerine devam edebildikleri bir sistemi ifade eder (Drucker, 1996, s.36).

YE kavramına ilişkin farklı tanımlar bulunmakla birlikte; mevzuat metinleri, kalkınma planları, alan uzmanları, eğiticiler gibi YE'ye farklı açılar- 
dan yaklaşan taraflarca kavram farklı yorumlanabilmektedir. Bununla birlikte tanımlarda ortaklaşan noktalar göz önünde bulundurulduğunda, YE kavramının öncelikle yetişkin bireylere yönelik bir eğitim öğretim faaliyeti olduğunu ve ayrıca birey ve toplumun ihtiyaçları çerçevesinde şekillendiğini söylemek olanaklıdır (Titmus, 1997, s.46; Başaran, 1996, s.76; Park, 2002, s.286).

Eğitim politikaların genel toplumsal değişim ve dönüşümlerden soyutlamak olanaksızdır. Makro düzeyde özellikle yirminci yüzyılın son çeyreğinde sosyo-ekonomik ve politik alanlarda önemli paradigmatik dönüşümler yaşanmıştır. Ekonomik serbestlik, liberal etkiler ve küreselleşme izleğindeki bu paradigmatik dönüşümler eğitim politikaları bağlamında genelde eğitim, özelde YE alanında da çok yönlü ve yüksek ivmeli bir değişim ve dönüşüm sürecinin tetikleyicisi olmuştur. Balc1 (1995), değişimi "bilginin patlaması, hızla ürün eskimesi, iş gücü yapısı, kişisel ve toplumsal sorunlara ilgi ve uluslararası oluş" biçiminde tanımlamaktadır. Nitekim küreselleşme sürecinde eğitimin önemi ve işlevi konusundaki söylemlerdeki hâkim vurgu da "innovasyon, bilgi toplumu, yaşam boyu öğrenme, öğrenen toplumlar, e-öğrenme" gibi kavramlarla ters yüz edilmeye başlanmıştır (Sayılan, 2009). Küreselleşmenin kendisi de yeni eğitim gereksinimlerine yol açmaktadır. Ulaşım, iletişim ve bilişim teknolojilerinin sağladığı kolaylıklar temelinde farklı uluslardan insanlar arasında etkileşim artmakta, fiziksel ve kültürel coğrafyalar arasındaki hareketlilik ivme kazanmaktadır (Miser, 2002). Bu değişim ve dönüşümlere bağll olarak bilgi-iletişim teknolojilerindeki ve dijital medyadaki gelişmeler doğrultusunda bilginin üretimi, yayılması ve kaynağ1 konusundaki gelişmeler, sözgelimi e-öğrenme modellerinin ve uzaktan öğrenme platformlarının geliştirilmesi ve yaygınlaştırılması gibi uygulamalar YE politikaları açısından giderek daha baskın bir ilgi alanı nesnesi haline gelmektedir.

Türkiye'de YE politikalarının 2010'lu yıllara dek temel referans noktasının, Avrupa Birliği üyelik süreci izleğinde şekillendiğini ifade etmek olanaklıdır. Nitekim Türkiye'de YE'ye yön veren temel mevzuatın, hayat boyu öğrenme strateji belgelerinin ve hayat boyu öğrenme bağlamındaki ulusal hedeflerin; Avrupa Birliği üyelik süreci eksenli yeni yapılanma ve dönüşümlerden belirgin izler taşıdığı söylenebilir. Öte yandan Türkiye'de özellikle 2010'lu yıllardan itibaren, genç nüfus yoğunluğu ve işsizlik baskısının yanı sıra mülteci krizi ile yeniden gündeme gelen okumaz-yazmazlık gibi 
sorunların üstesinden gelinmesinde geçici çözümlerden öte YE'de yeni politika ve uygulamalara şiddetle ihtiyaç duyulmaktadır. Nitekim Türkiye'de YE faaliyetlerine katılım oranlarına bakıldığında; 2019 yılı verilerine göre $\% 5$ olan Türkiye'nin yüz yüze gerçekleştirilen YE faaliyetlerine katılım oranının; gerek OECD ülkeleri ortalamasının gerek $\mathrm{AB}$ ülkeleri ortalamasının gerekse de \%15 olarak belirlenen $A B 2020$ YE katılım oranı hedefinin çok uzağında olduğu görülmektedir (OECD, 2019; Eurostat, 2019). UNHCR (2020) verilerine göre Türkiye'de kayıtlı mülteci sayısı 4 milyona ulaşmış olup, Türkiye'deki mülteci sayısı dünyadaki 61 ülke nüfusundan daha fazladır. Bunun ise anılan 4 milyon mülteci açısından başta dil eğitimi ve okuma-yazma olmak üzere yeniden tanımlanan öğrenme ihtiyaçları anlamına geldiği söylenebilir. Türkiye'nin kendine özgü eğitim ihtiyaçları bulunmasına rağmen salt Avrupa Birliği'ne üyeliği hedef alan düzenlemeler, Türkiye'nin eğitim ihtiyaçlarının giderilmesinde çözüm olmaktan uzak kalmaktadır (Bağ Cl, 2011).

Türkiye'de YE politikalarına örgütsel bağlamda bakıldığında, makro ölçekli neo-liberalizasyon sürecine bağlı olarak örgütsel yapılanmada yetkinin yerele devri, esneklik, yetkinin dağıtılması gibi modellerin aksine; merkezi yönetim anlayışının egemen olduğu görülmektedir. YE alanında liberal paradigma ağırlık kazanarak, 'kişisel gelişim' artık en iyi ihtimalle verimlilik stratejileri çerçevesinde, bireylerin daha hızlı ve etkin niteliklendirilmesi anlayışına dönüşmekte, bu süreçlerin dışında kalanlar ise unutulmaktadır (Sayılan, 2009).

Türkiye'de YE sistemini; politik ve stratejik özelliklerine, örgütsel özelliklerine ve uygulamalara göre analiz edebilmek, değişkenler arasındaki ilişkileri ortaya koyabilmek ve YE sürecine katılım açısından özel ilgi bekleyen olası grupları ve alanları tespit etmek önemli bir sorun alanıdır. Nitekim OECD (2019) tarafından yapılmış olan araştırmada 25-64 yaş gruplarındaki bireylerin YE faaliyetlerinden yararlanma durumuna göre ülkeler siraland1ğında İsviçre, Hollanda, İsveç ve Yeni Zelanda'nın tüm mezuniyet düzeylerinde yetişkin katılımında OECD ülkeleri içerisinde başı çekmektedir. Bununla birlikte; Rusya Federasyonu, Polonya ve Yunanistan ile birlikte Türkiye OECD ülkeleri içerisinde son sıraları paylaşmaktadır (OECD, 2019). 2564 yaş gruplarındaki bireylerin YE faaliyetlerinden yararlanma durumuna göre Türkiye, OECD ülkeleri ortalamasının çok uzağında bulunmaktadır. Bu veriler ışığında, Türkiye'de YE'nin toplumda daha etkili bir biçimde 
kabul görmesini sağlayacak çalışmaların yanı sıra, YE ihtiyaçlarını belirleme, gözlenebilir-ölçülebilir hedefler oluşturma, program ve planlama çalışmaları, katılma engelleri, YE strateji ve teknikleri, eğitim ortamları, değerlendirme-izleme ve yeni YE politikalarının işe koşulması boyutlarında gözden geçirmeler ve değerlendirmeler yapılması gerektiği açıktır.

Alanyazında YE üzerine yapılmış olan araştırmalar incelendiğinde; araştırmaların çoğunlukla eğitici niteliklerine ve eğiticler ile kursiyerlerin demografik niteliklerine odaklandığı (Miser, Ural ve Ünlühisarcıklı, 2013; A $\breve{g}$ cihan, 2015; Babanll, 2018) görülmektedir.

Miser, Ural ve Ünlühisarcıklı (2013) tarafından yapılan betimsel çalışmada Millî Eğitim Bakanlığı tarafından yıllık olarak yayınlanan raporlarda yer alan 2000 ile 2008 yılları arasındaki verilerin derlenmesini temele alınmıştır. Araştırma sonucunda; Türkiye'de YE alan kişilerin çoğunun erkek olduğu, YE alan kişi sayısının genel nüfusa oranlandığında katılım oranlarının oldukça düşük olduğu bulguları ortaya konmuştur (Miser vd., 2013).

Ağcihan (2015) tarafından, YE alanında eğitim veren eğitmenlerin yeterlilik düzeylerini belirlemek amacıyla yapılan, ilişkisel tarama modelindeki nicel araştırmada, kursiyerlerin demografik yapısına göre ifadelere vermiş oldukları cevapların anlamlı olarak değişip değişmediği araştırılmıştır. Araştırma sonucunda; erkeklerin kadınlara göre kursu bitirdikten sonra ekonomik hayata daha fazla katıldıkları sonucuna ulaşılmıştır. Bununla birlikte, kadın kursiyerlerin erkek kursiyerlere göre "katıldığım kurs hayatıma anlam kazandırmıştır" ifadesini daha fazla belirttiği, ilköğretim ve orta öğretim mezunu kursiyerlerin lisansüstü mezunu kursiyerlere göre daha fazla "katıldığım kurs sahip olduğum yetenekleri keşfetmemi sağlamıştır" ifadesini belirttiğisonucuna ulaşılmıştır. Meslek edinmek için katılan kursiyerlerin "öğrendiğim bilgileri günlük hayatta kullanabiliyorum" ifadesini daha fazla belirttiği konusu ise araştırmada ulaşılan bir başka sonuçtur (A $\breve{g}$ cihan, 2015).

Babanlı (2018) tarafından yapılan nicel araştırmada YE'deki kursiyerlerin yaşam boyu öğrenme yeterlilik düzeylerinin belirlenmesi; bu yeterlilik düzeylerinin cinsiyet, yaş, medeni hal, öğrenim düzeyi, özel veya resmi yaygın eğitim kurumları tarafından verilen kurslara katılıp katılmama durumu ve eğer katılmışsa katılım süresi değişkenlerine göre incelenmesi amaçlanmıştır. Bu amaç doğrultusunda araştırmacı tarafından 'Yaşam Boyu Öğrenme Yeterlilik Ölçeği' geliştirilmiş ve 2017-2018 eğitim öğretim yılında 
İstanbul ili Fatih ilçesindeki İSMEK kurslarında öğrenim gören 134'ü kadın, 112'si erkek olmak üzere toplam 246 kursiyere ölçek uygulanmıştır. Araştırma sonucunda kursiyerlerinin yaşam boyu öğrenme yeterlilik düzeylerinin medeni hal ve kurslara katılım süresine göre anlamlı bir farklılık göstermediği ortaya konmuştur. Ancak, cinsiyete, yaşa, öğrenim durumu ve kurslara katılıp katılmama durumuna göre farklılık gösterdiği sonucuna ulaşılmıştır (Babanlı, 2018).

Araştırmada Türkiye'de yetişkin eğitiminin politik ve stratejik özelliklerini, örgütsel yapısını ve uygulamalarını kursiyer görüşlerine göre analiz etmeye yönelik Yetişkin Eğitimi Analiz Ölçeği Kursiyer Formu'nu geliştirmek ve kursiyerlerin görüşlerine göre yetişkin eğitimini çeşitli değişkenler açısından incelemek amaçlanmıştır. . Bu bağlamda çalışmanın, Türkiye'de YE'nin toplumda daha etkili bir biçimde kabul görmesini sağlayacak çalışmalara referans olmasının yanı sıra, YE ihtiyaçlarını belirleme, gözlenebilirölçülebilir hedefler oluşturma, program ve planlama çalışmaları, katılma engelleri, YE strateji ve teknikleri, eğitim ortamları, değerlendirme-izleme ve yeni YE politikalarının işe koşulması boyutlarında gereksinim duyulan verilerin toplanmasına kaynaklık oluşturması beklenmektedir. Bu bağlamda araştırma, kuram ve uygulamaya yönelik vizyon geliştirme olanaklarına yönelik veri toplamak için bir ölçme aracı ortaya koymak bakımından önem taşımaktadır.

\section{Araştırmanın amacı}

Bu araştırmanın amacı Türkiye'de yetişkin eğitiminin politik ve stratejik özelliklerini, örgütsel yapısını ve uygulamalarını kursiyer görüşlerine göre analiz etmeye yönelik Yetişkin Eğitimi Analiz Ölçeği Kursiyer Formu'nu geliştirmek ve kursiyerlerin görüşlerine göre yetişkin eğitimini çeşitli değişkenler açısından incelemektir. Bu amaçla aşağıdaki sorulara yanıt aranmıştır:

1. Türkiye'de yetişkin eğitimini kursiyerlerin görüşlerine göre değerlendirmeye yönelik nasıl bir ölçek ortaya konulabilir?

2. Kursiyerlerin Türkiye'de yetişkin eğitiminin politik ve stratejik özelliklerine, örgütsel yapısına ve uygulamalarına ilişkin görüşleri;

a) Yaşa

b) Cinsiyete 
c) katıldıkları kurs sayısına

d) eğitim durumuna

e) mesleğe

göre farklılık göstermekte midir?

\section{Yöntem}

Araştırmanın birinci aşamasında Türkiye'de yetişkin eğitiminin politik ve stratejik özelliklerini, örgütsel yapısını ve uygulamalarını kursiyer görüşlerine göre analiz etmeye yönelik Yetişkin Eğitimi Analiz Ölçeği Kursiyer Formu'nu geliştirmek amaçlanmıştır.

Araştırmanın ikinci aşaması betimsel tarama modelinde tasarlanmıştır. Tarama modelleri, geçmişte veya halen var olan bir durumu, olduğu şekli ile betimlemeyi amaçlayan araştırmalar için uygun bir modeldir (Karasar, 2007). Tarama modelinde bilimin gözleme, kaydetme, olaylar arasındaki ilişkileri tespit etme, kontrol edilen değişmez ilişkiler üzerinde genellemelere varma bulunur (Karasar, 2007, s.79). Araştırmada olası değişkenlik ilişkilerinin incelenmesi amaçlanmıştır. Bu nedenle araştırmada ilişkisel tarama yöntemi kullanılmıştır. İlişkisel tarama yöntemi; betimsel tarama modellerinden, genel tarama modelleri kapsamında ele alınan bir yöntemdir. İlişkisel tarama modelleri, iki ve daha çok değişken arasındaki birlikte değişim ilişkisini; varlığını, yokluğunu, yönünü veya derecesini belirlemeyi amaçlayan araştırma modelleri için kullanılır (Cohen, Manion ve Morrison, 2000).

\section{Katılımcılar}

Araştırmanın Yetişkin Eğitimi Analiz Ölçeği Kursiyer Formu'nun geliştirilmesi aşamasındaki örneklemine ilişkin bilgilere Aşama 1 başlığ 1 altında, kursiyer görüşlerinin çeşitli değişkenler açısından incelenmesi boyutundaki örnekleme ilişkin bilgilere ise Aşama 2 başlığı altında yer verilmektedir.

Aşama 1: Aday ölçme aracının ön deneme aşamasında 6'sı kadın 5'i erkek toplam 11 kursiyer ile yüz yüze görüşmeler gerçekleştirilmiştir. Ön deneme aşamasından sonra aday ölçme aracına son şeklinin verilmesinin ardından zaman ve maliyet açısından kolay ulaşılabilirlik dikkate alınarak seçilen, 2017 yılı Kasım ayı itibariyle en az bir kursu tamamlamış ya da devam et- 
mekte olan 397 kursiyer ile çalışılmıştır. Alanyazında ölçek geliştirmek için 300 kişilik örneklemin yeterli olacağı önerilmiştir. (Henson ve Roberts, 2006; Worthington ve Whittaker, 2006). Bu bağlamda örneklemin yeterli olduğu düşünülmektedir.

Aşama 2: Araştırmanın ikinci aşamasında evren ve örneklem, Eskişehir ili merkez ilçelerdeki YE kurumlarında, araştırmanın planlandığı 2017-2018 eğitim-öğretim yılı Kasım ayı itibariyle kurs süreci aktif durumda bulunan kayıtlı kursiyer sayısı dikkate alınarak belirlenmiştir. Buna göre Eskişehir merkez ilçelerde, 2017-2018 eğitim-öğretim dönemi Kasım ayında toplam 6.242 aktif kursiyer bulunmaktadır. Bu kursiyerlerden 3.244'ü Odunpazarı Halk Eğitimi Merkezinde, 2.998'i Tepebaşı Halk Eğitimi Merkezinde olmak üzere toplam 6.242 kursiyer, araştırmanın kursiyer evrenini oluşturmaktadır. Araştırmanın kursiyer boyutunda +-0.05 örnekleme hatası baz alınarak 614 katılımcıdan oluşan bir örneklem büyüklügüne ulaşılmıştır. Bu katılımcıların seçiminde yine veri çeşitlemesi ile zaman ve maliyet unsurları da göz önünde bulundurulup kolay ulaşılabilirlik dikkate alınarak; en popüler/en çok katılım sağlanan 10 kurstan herhangi birine devam etmekte olan kursiyerler içerisinden tabakalı örnekleme yoluyla, ilgili kurslara ilişkin 20172018 eğitim-öğretim yılı Kasım ayı kursiyer sayısı ile orantılı olarak örneklem seçimi yapılmıştır.

\section{Veri Toplama Araçlanı ve Verilerin Toplanması}

Araştırmanın Yetişkin Eğitimi Analiz Ölçeği Kursiyer Formu'nun geliştirilmesi aşamasındaki veri toplama araçları ve verilerin toplanmasına ilişkin bilgilere Aşama 1 başlı̆̆ altında, kursiyer görüşlerinin çeşitli değişkenler açısından incelenmesi boyutundaki bilgilere ise Aşama 2 başlı̆̆ altında yer verilmektedir.

Aşama 1: Aday ölçme aracı için gerekli madde havuzu, uzman görüşü al1narak oluşturulmuştur. Uzman görüşleri doğrultusunda gerekli görülen düzeltmeler yapıldıktan sonra ön deneme aşamasına geçilmiştir. Ön deneme aşamasında 11 kursiyer ile yüz yüze görüşmeler gerçekleştirilmiştir. Yüz yüze görüşmelerden elde edilen geri bildirimler doğrultusunda maddelere ilişkin ifade biçimlerinde anlaşılırlığı sağlamak için düzeltme ve değişiklik- 
ler yapılmıştır. Sonuç olarak iki bölümden oluşan aday ölçme aracının birinci bölümünde kişisel bilgilere, ikinci bölümünde ise yetişkin eğitiminin analizine yönelik veri toplamayı amaçlayan sorulara yer verilmiştir. Araştırmada 36 madde ile analize başlanmış ancak öz değeri 1 ve üzeri olan teorik olarak anlamlı 3 faktörlü 17 maddeli bir ölçek ortaya konulmuştur.

Aşama 2: Araştırmada Türkiye'de YE sistemini; politik ve stratejik, örgütsel ve uygulamaya dönük özelliklerine göre analiz edebilmek ve değişkenler arasındaki ilişkileri ortaya koyabilmek amacıyla "Yetişkin Eğitimi Analiz Ölçeği Kursiyer Formu (YEAK)" sonuçlarından faydalanılmıştır.

Bireylerin sahip oldukları özelliklerin, ifade ettikleri davranışların, taşıdıkları fikir ya da kanılar ile sahip oldukları tutumun öğrenilmesi için en dikkate değer kaynak onların kendi yazılı ve sözlü ifadeleridir (Balcı, 2001). Bu bağlamda geliştirilmiş olan pek çok teknikten biri olan ölçek, bilgi toplama yöntemleri arasında, çalışmanın konusunu oluşturan kişilerin diğerleri tarafından gözlemlenemeyen davranış kodlarının ortaya çıarmış olduğu "uyarım, yansıma, tutum, düşünce ve yaşantılarına" yönelik enformasyonu bir araya getirme konusunda çok etkili olarak görülmektedir (Özoğlu, 1992). Ölçek, toplum ile ilgili olan pek çok konuda objektif bilgiye sahip olmak için kullanılan önemli bir veri toplama aracıdır (Gökçe, 2004). Bu veri toplama aracı, araştırmacının bireysel katılımı olmaksızın, bireysel olmadan, doğrudan araştırma kapsamındaki hedef kitleye sorulan sorulardan oluşmaktadır (Ekiz, 2003).

Araştırmada alan yazına dayalı olarak geliştirilen ölçme aracı olan "Yetişkin Eğitimi Analizi Ölçeği Kursiyer Formu (YEAK)" için gerekli madde havuzu, uzman görüşü alınarak oluşturulmuştur. Uzman görüşleri doğrultusunda gerekli görülen düzeltmeler yapıldıktan sonra öndeneme aşamasına geçilmiştir. Ön deneme aşamasında 6'sı kadın 5'i erkek toplam 11 kursiyer; yüz yüze görüşmeler gerçekleştirilmiştir. Sonuç olarak iki bölümden oluşan ölçme aracının birinci bölümünde kişisel bilgilere, ikinci bölümde YE'nin analizine yönelik veri toplamayı amaçlayan sorulara yer verilmiştir.

Ölçekte "yüzeysel geçerlilik, bir ölçek ve/veya testin araştırılan yapıyı ölçüp ölçmediğine yönelik araştırmacının, kendisinin, yakın çevresinin, araştırılan konuya ilişkin uzman olmayan farklı bireylerin ve pilot araştırmaya katılmış olan yanıt verenlerin fikir ve düşüncelerinin bir araya getirilmesiyle elde edilmektedir (Şencan, 2005). Bu çalışma kapsamında ölçek soruları 
araştırmacı tarafından hazırlanmıştır. Bir ölçme sonucunun geçerli olabilmesinin ana şartı onun güvenilir olmasıdır (Karasar, 2007). Ölçek güvenilirliği, bir ölçme aracı tarafından, ölçülmesi hedeflenen özelliğin ne kadar doğru ölçülüp ölçülmemesinin anlaşılması anlamına gelir (Hovardaoğlu, 2000). Çoğunlukla ölçeğin güvenilir olması için, ölçeceği özelliği tutarlı ve geçerli şekilde ölçmesi ve yeniden elde edilebilen sonuçlar ortaya çıkarması gerekmektedir (Özdamar, 2004).

Ölçme aracının kapsam geçerliliği uzman görüşlerine göre, yapı geçerliği açımlayıcı ve doğrulayıcı faktör analizlerine dayalı olarak, ölçme aracı ve alt boyutlarının güvenirliliği ise Cronbach Alfa Güvenirlik Katsayısının uygunluk aralığına göre sağlanmıştır.

Bu çalışma kapsamında güvenilirliğin ölçümü için test-tekrar test yöntemi kullanılmıştır. Bu yöntem ile güvenilirliğin tahmin edilebilmesi için, bir ölçek formunun yerlerinin değişmiş başka bir versiyonun daha olması gerekmektedir. Bu farklı görünen iki form aynı gruba uygulandıktan sonra iki sonuç arasındaki korelasyona bakılmaktadır. Her iki form art arda uygulanabileceği gibi belirli süre aralıklarıyla da uygulanabilmektedir (Douglas, 2002, s.336). Böylece güvenilirlik elde edilmiş olmaktadır.

\section{Verilerin Analizi}

Araştırmanın Yetişkin Eğitimi Analiz Ölçeği Kursiyer Formu'nun geliştirilmesi aşamasındaki verilerin analizine ilişkin bilgilere Aşama 1 başlı̆̆ altında, kursiyer görüşlerinin çeşitli değişkenler açısından incelenmesi boyutunda verilerin analizine ilişkin bilgilere ise Aşama 2 başlı̆̆ı altında yer verilmektedir.

Aşama 1: Yetişkin Eğitimi Analiz Ölçeği Kursiyer Formu'nun geliştirilmesi aşamasında açımlayıcı faktör analizi için örneklem uygunluğunu test etmek amaciyla Kaiser-Meyer-Olkin örneklem uygunluk testi; faktör analizi yapmaya uygunluk içinse Barlett küresellik testi sonuçlarından yararlanılmıştır. Açımlayıc faktör analizi için sosyal bilimler için maksimum olabilirlik yöntemi önerildiğinden (Haig, 2005; Fabrigar vd., 1999; Nunnally ve Bernstein, 1994; Worthington ve Whittaker, 2006) bu yöntem işe koşulmuştur. Benzer şekilde sosyal bilimler için döndürme yöntemlerinden faktörlerin birbirle- 
riyle ilişkili olduğu durumlar için eğik döndürme olan promax tercih edilmiştir (Fabrigar vd., 1999; Ford, MacCallum ve Tait, 1986; Gorsuch, 1997).

Faktör sayısın belirlemek amacı ile öz değerler ve çizgi grafiği (scree plot) göz önünde bulundurulmuştur (Goldberg ve Velicer, 2006; Kline, 2013; Worthington ve Whittaker, 2006). Faktörlerde bulunacak madde sayısı için karar verilirken en düşük faktör yükünün 32 olması (Worthington ve Whittaker, 2006) maddelerin binişik olmaması, her bir faktör altında en az 3 maddenin olması, güvenirliğin yeterli olması ve son olarak teorik düzeyde anlamlı olması koşuları dikkate alınmıştır (Costello ve Osborne, 2005; DeVellis, 2012; Fabrigar vd., 1999; Gorsuch, 1997; Kline, 2013; Norris ve Lecavalier, 2010; Tabachnick ve Fidell, 2007; Worthington ve Whittaker, 2006).

Aşama 2: Araştırmanın ikinci aşamasında veriler araştırmacılar tarafından geliştirilen "Yetişkin Eğitimi Analiz Ölçeği Kursiyer Formu" aracilığıyla toplanmıştır. Analizler; kayıp ve uç değerler veri setinden ayıklandıktan sonra geriye kalan toplam 614 katılımcıdan sağlanan veriler üzerinden gerçekleştirilmiştir. Verilerin analizinde SPSS 25.0 paket programı kullanılmıştır. Araştırmanın nicel verilerin çözümlenmesinde Kursiyerlerin, Türkiye'de yetişkin eğitiminin politik ve stratejik özelliklerine, örgütsel yapısına ve uygulamalarına ilişkin görüşlerinin;

1. Cinsiyete göre değişiminin analizine ilişkin bağımsız gruplar T-testi;

2. Yaşa, deneyime, öğrenim durumuna, yapmakta oldukları işe göre değişiminin analizine ilişkin ise Çok Değişkenli Varyans Analizi (MANOVA) uygulanmıştır.

Araştırmada tip 1 hatayı önlemek amacı ile univarite testleri için Bonferoni protokolü işe koşulmuştur (Huck, 2012; Pallant, 2007). P değeri olan 0.05 bağımlı değişken olan 3'e bölünmüş ve yeni $\mathrm{P}$ değeri hesaplanmıştır. Ayrıca anlamlı sonuçların olduğu durumlarda univarite testlerinden sonra varyanslar eşit ise Tukey testi, değil ise Tamhane testi kullanılmıştır.

\section{Bulgular}

Araştırmanın Yetişkin Eğitimi Analiz Ölçeği Kursiyer Formu'nun geliştirilmesi aşamasındaki bulgulara Aşama 1 başlığı altında, kursiyer görüşlerinin çeşitli değişkenler açısından incelenmesi boyutundaki bulgulara ise Aşama 2 başlığı altında yer verilmektedir. 
Aşama 1: Aşama 1 başlığı altında Araştırmanın Yetişkin Eğitimi Analiz Ölçeği Kursiyer Formu'na ilişkin açımlayıcı ve doğrulayıcı faktör analizlerine yer verilmektedir.

\section{Yetişkin Eğitimi Analiz Ölçeği Kursiyer Formu açımlayıcı faktör analizi} sonuçları: Araştırmada YEAK'ın yapısını ortaya koymak için açımlayıcı faktör analizi yapılmıştır. Verilerin normalliği ve kayıp veriler incelenmiş, verilerin normal olduğu ve kayıp veri olmadığı tespit edilmiştir. Analizde örneklemin uygunluğu kontrol edilmiştir. Örneklem için 300 kişinin yeterli

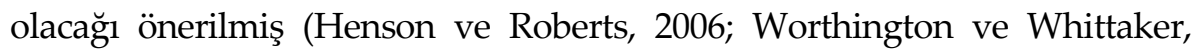
2006) bu çalışmada kolayda örnekleme yoluyla seçilen 397 kursiyer ile çallşılmıştır. Ayrıca örneklem yeterliliği için Kaiser-Meyer-Olkin örneklem uygunluk katsayısının .84 olduğu yani iyi düzeyde olduğu, faktör analizi yapmaya uygunluk için Barlett küresellik testi sonuçlarına bakılmış $\chi 2=$ 2584,236 ( $\mathrm{p}<.001$ ) ve verinin uygun olduğu tespit edilmiştir (Comrey ve Lee, 1992; McCrosky ve Young, 1979; Tabachnick ve Fidell, 2007).

Açımlayıcı faktör analizi için sosyal bilimler için maksimum olabilirlik yöntemi önerildiğinden (Haig, 2005; Fabrigar vd., 1999; Nunnally ve Bernstein, 1994; Worthington ve Whittaker, 2006) bu yöntem işe koşulmuştur. Benzer şekilde sosyal bilimler için döndürme yöntemlerinden faktörlerin birbirleriyle ilişkili olduğu durumlar için eğik döndürme olan promax tercih edilmiştir (Fabrigar vd., 1999; Ford, MacCallum ve Tait, 1986; Gorsuch, 1997).

Faktör sayısını belirlemek amacı ile öz değerler ve çizgi grafiği (scree plot) göz önünde bulundurulmuştur (Goldberg ve Velicer, 2006; Kline, 2013; Worthington ve Whittaker, 2006). Faktörlerde bulunacak madde sayısı için karar verilirken en düşük faktör yükünün 32 olması (Worthington ve Whittaker, 2006) maddelerin binişik olmaması, her bir faktör altında en az 3 maddenin olması, güvenirliğin yeterli olması ve son olarak teorik düzeyde anlamlı olması koşuları dikkate alınmıştır (Costello ve Osborne, 2005; DeVellis, 2012; Fabrigar vd., 1999; Gorsuch, 1997; Kline, 2013; Norris ve Lecavalier, 2010; Tabachnick ve Fidell, 2007; Worthington ve Whittaker, 2006).

Araştırmada 36 madde ile analize başlanmış ancak yukarıda sayılan kriterlere uyan teorik olarak anlamlı 3 faktörlü 17 maddeli bir ölçek ortaya konulmuştur. Ölçeğe ilişkin çizgi grafiği Şekil 1'de sunulmuştur. Buna göre öz değeri 1 ve üzeri olan ve keskin çıkışın olduğu yerden itibaren üç faktör 
kabul edilmiştir. (McCroskey ve Young, 1979; Pett, Lackey ve Sullivan, 2003; Preacher ve MacCallum, 2003).

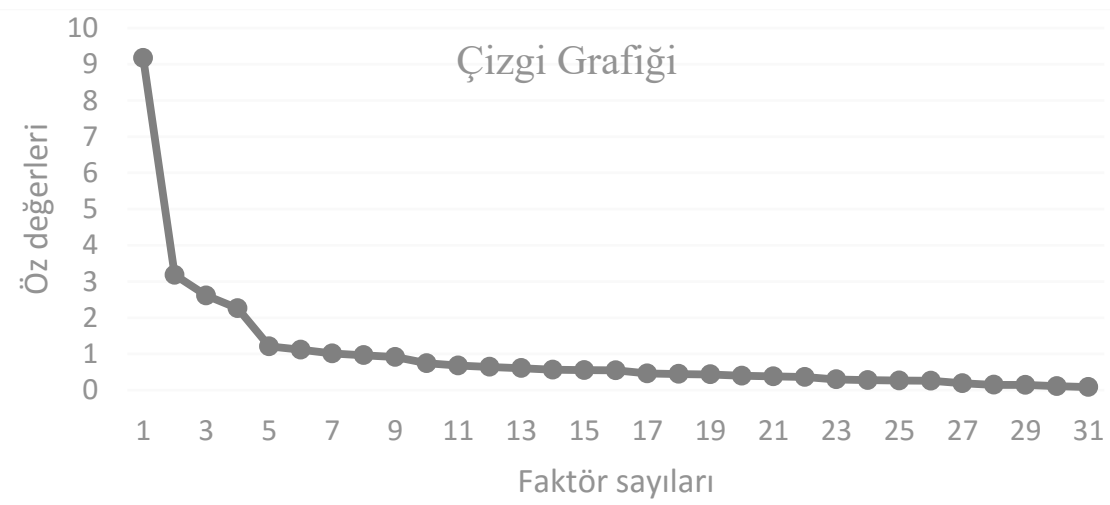

\section{Şekil 1. YEAK Çizgi Grafĭği}

Çalışmada ortaya konulan 3 faktörlü 17 maddelik ölçeğe ilişkin madde faktör yükleri, ortalamaları, standart sapmaları, açıkladıkları varyans, madde korelasyonları ve iç tutarlılık katsayıları bilgileri Tablo 1'de verilmiştir.

Tablo 1.YEAK madde ortalamalarn, standart sapmalar, madde toplam korelasyonlarn, faktör yükleri, güvenirlik katsayılar ve açıkladıkları varyansa ilişkin bulgular

\begin{tabular}{|c|c|c|c|c|c|}
\hline Faktörler ve maddeler & Açıklanan varyans (\%) & $\overline{\mathbf{x}}$ & Ss & $\begin{array}{l}\text { Madde } \\
\text { toplam }\end{array}$ & $\begin{array}{l}\text { Faktör } \\
\text { yükü }\end{array}$ \\
\hline \multicolumn{6}{|l|}{ Örgütsel Yapt $(\alpha=0,65)$} \\
\hline M1 & \multirow{5}{*}{10,86} & 4,61 & 0,604 & 0,163 & 0,707 \\
\hline M2 & & 4,64 & 0,541 & 0,229 & 0,653 \\
\hline M3 & & 4,37 & 0,691 & 0,310 & 0,642 \\
\hline M4 & & 4,42 & 0,657 & 0,365 & 0,610 \\
\hline M5 & & 4,45 & 0,628 & 0,265 & 0,550 \\
\hline \multicolumn{6}{|l|}{ Uygulama $(\alpha=0,84)$} \\
\hline M6 & \multirow{8}{*}{26,2} & 3,65 & 1,032 & 0,619 & 0,799 \\
\hline M7 & & 3,56 & 1,049 & 0,636 & 0,753 \\
\hline M8 & & 3,59 & 1,052 & 0,520 & 0,745 \\
\hline M9 & & 3,78 & 1,078 & 0,554 & 0,707 \\
\hline M10 & & 3,47 & 1,109 & 0,516 & 0,688 \\
\hline M11 & & 3,30 & 1,137 & 0,555 & 0,639 \\
\hline M12 & & 3,54 & 1,151 & 0,473 & 0,588 \\
\hline M13 & & 4,04 & 1,029 & 0,429 & 0,516 \\
\hline
\end{tabular}




\begin{tabular}{|c|c|c|c|c|c|}
\hline M14 & & 4,32 & 0,769 & 0,442 & 0,496 \\
\hline \multicolumn{6}{|c|}{ Politik Ve Stratejik $(\alpha=0,60)$} \\
\hline M15 & & 2,36 & 0,813 & 0,086 & 0,883 \\
\hline M16 & 10,26 & 2,34 & 0,808 & 0,096 & 0,844 \\
\hline M17 & & 2,56 & 1,054 & 0,215 & 0,442 \\
\hline Toplam $(\alpha=0,79)$ & 47,32 & & & & \\
\hline
\end{tabular}

Tabloda görüldüğü üzere toplam varyansın \% 47,32'sini açıklayan, 17 maddeli ve öz değerleri 1.00 'in üzerinde olan 3 faktörlü yapı ortaya konulmuştur. Örgütsel yapı boyutu varyansın yüzde 10.86 'sını, uygulama boyutu 26.2 'sini, ve son olarak politik ve stratejik boyut ise varyansin yüzde 10.26 'sını açıklamaktadır. Ölçek maddelerinin faktör yükleri .44 ile .88 arasinda bulunmaktadır. Alanyazında .40 ve üzerinin iyi faktör yükü olduğu belirtilmiştir (Pallant, 2007).

Yetişkin Ĕ̆itimi Analiz Ölçeği Kursiyer Formu doğrulayıcı faktör analizi sonuçları: YEAK doğrulayıcı faktör analizi yapılmadan önce verilerin uzaklık değerleri hesaplanmıs ve normallik şartının sağlanıp sağlanmadığı kontrol edilmiştir. Yapılan uzaklık değerleri analizi sonucunda veri setinden 17 kişi çıkarılmıştır. Sonuç olarak analizler 598 kişi üzerinden yürütülmüştür. Ayrıca verilerin normal sınırlar içinde olduğu tespit edilmiştir.

YEAK için yapılan ilk doğrulayıcı faktör analizi sonuçlarından uyum indekslerinin istenen aralıklarda olmadığı görülmüştür. Ancak uygulama boyutu madde 4 ile madde 7 arasinda yapılan hata kovaryansı neticesinde istenen sonuçlar elde edilmiştir. Buna göre Ki-kare (405) serbestlik derecesi (115) oranı (X2/df) 3.5; Karşılaştırmalı Uyum İndeksi (CFI) .93; Tucker Lewis Indeksi TLI .92; Normlaştırılmamış Uyum İndeksini (NNFI) .92; Bollen Uyum İndeksinin (IFI) .93; Tahmin Hatalarının Ortalamasının Karekökü (RMSEA) .06; Standartlaştırılmış Hata Kareleri Ortalamasının Karekökü (SRMR) .05 ve İyilik Uyum İndeksi (GFI) 92 olarak tespit edilmiştir. Bu bulgulara göre ölçeğin iyi uyum değerlerine sahip olduğu söylenebilir (Bkz. Tablo 2). 
Tablo 2. YEAK maddeleri ortalama, standart sapma ve faktör yükleri $(n=598)$

\begin{tabular}{llllllll}
\hline Faktörler & Maddeler & $\mathbf{X}$ & ss & Faktör yükü & Std. hata & z-değeri & P \\
\hline Örgütsel Yap1 & or1 & 4,65 & 0,525 & 0.28 & 0.02 & 11.59 & $<.001$ \\
& or2 & 4,63 & 0,494 & 0.27 & 0.02 & 12.66 & $<.001$ \\
& or3 & 4,38 & 0,673 & 0.43 & 0.03 & 14.84 & $<.001$ \\
& or4 & 4,41 & 0,671 & 0.45 & 0.03 & 15.70 & $<.001$ \\
& or5 & 4,46 & 0,610 & 0.34 & 0.03 & 12.63 & $<.001$ \\
\hline Uygulama & uy1 & 3,48 & 1,013 & 0.83 & 0.04 & 23.20 & $<.001$ \\
& uy2 & 3,44 & 1,043 & 0.88 & 0.04 & 24.48 & $<.001$ \\
& uy3 & 3,46 & 1,041 & 0.80 & 0.04 & 21.29 & $<.001$ \\
& uy4 & 3,59 & 1,134 & 0.65 & 0.04 & 14.86 & $<.001$ \\
& uy5 & 3,36 & 1,098 & 0.81 & 0.04 & 20.24 & $<.001$ \\
& uy6 & 3,24 & 1,097 & 0.84 & 0.04 & 21.21 & $<.001$ \\
& uy7 & 3,45 & 1,143 & 0.59 & 0.05 & 12.78 & $<.001$ \\
& uy8 & 4,04 & 0,981 & 0.43 & 0.04 & 10.61 & $<.001$ \\
& uy9 & 4,29 & 0,767 & 0.35 & 0.03 & 11.09 & $<.001$ \\
\hline Politik Ve Stratejik & pol1 & 2,35 & 0,823 & 0.81 & 0.05 & 16.20 & $<.001$ \\
& pol2 & 2,34 & 0,825 & 0.70 & 0.05 & 15.02 & $<.001$ \\
& pol3 & 2,48 & 0,939 & 0.29 & 0.04 & 5.57 & $<.001$ \\
\hline
\end{tabular}
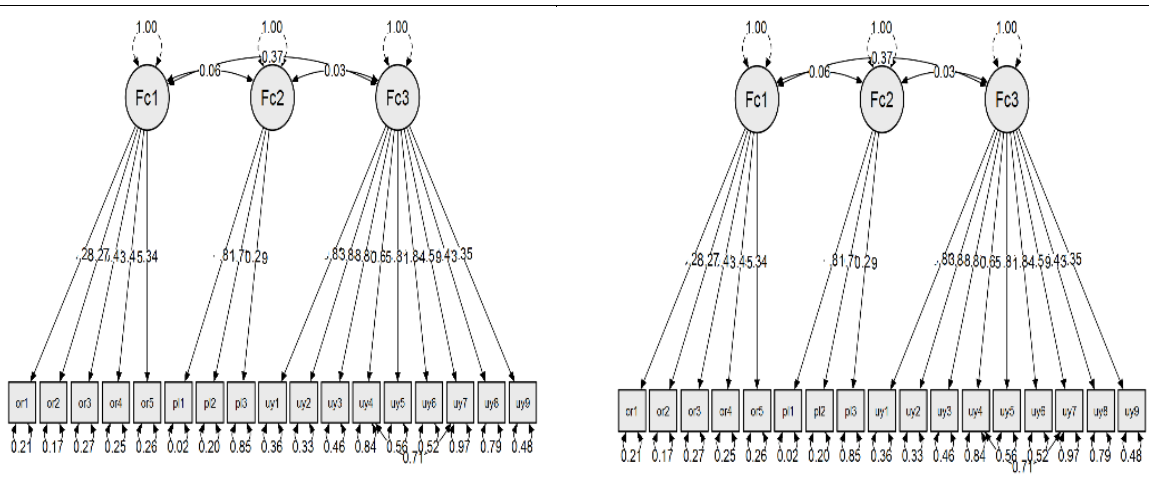

Şekil 2. YEAK Doğrulayıcı Faktör Analizi Grafiksel Gösterimi

Ölçeğin sağlam bir yapıya sahip olması için faktör yüklerinin belirlenen aralıkta olması gerekmektedir. Faktör yükleri için .60 üstü çok yüksek, .30.59 arası orta düzey ve son olarak .30 altı düşük sayılmaktadır (Büyüköztürk, 2010). Tabloda görüldüğü üzere maddeler genel yapı ile anlamlı ilişki göstermektedir. Örgütsel yapı alt boyutundaki madde 1 ve madde 2 ile politik ve stratejik alt boyutundaki madde 17 'nin faktör yükleri düşük olsa da gerek genel varyansa olan katkıları gerek yapı içindeki işlevlerinden dolayı ölçekte kalmalarına karar verilmiştir. Ölçeğe ilişkin grafiksel gösterim Şekil 2'de sunulmuştur: 
Ölçeğin son hali üzerinden güvenirlik analizleri tekrar yapılmıştır. Bu analizlere ilişkin bulgular Tablo 3 'te verilmiştir. Buna göre genel ölçeğin McDonald Omega değeri .85; Cronbach Alfa değeri .84 olarak tespit edilmiştir. Alt boyutlar için de örgütsel yapı için McDonald Omega değeri .74 ve Cronbach Alfa değeri .74, uygulama boyutu için McDonald Omega değeri .88 ve Cronbach Alfa değeri .88 ve son olarak politik ve stratejik boyut için McDonald Omega değeri .79 ve Cronbach Alfa değeri .70 olarak tespit edilmiştir. Elde edilen bu bulgular sonucunda ölçeğin güvenilir olduğu söylenebilir.

Tablo 3. YEAK Güvenirlik analizleri

\begin{tabular}{llll}
\hline Faktör adı & Madde sayısı & McDonald $\omega$ & Cronbach $\alpha$ \\
\hline Örgütsel Yapı & 5 & 0.74 & 0.74 \\
Uygulama & 9 & 0.88 & 0.88 \\
Politika ve Strateji & 3 & 0.79 & 0.70 \\
Genel Ölçek & 17 & 0.85 & 0.84 \\
\hline
\end{tabular}

Araştırmada YEAK için test-tekrar test güvenirliğinin test edilmesi amaçlanmıştır. Bu amaç doğrultusunda 60 kursiyere 21 gün ara ile ölceğin son hali uygulanmış ve aralarındaki korelasyon incelenmiştir. Buna göre testler arasındaki korelasyonun .86 olduğu yani ölçeğin test-tekrar test güvenirliğinin sağlandığg görülmüştür.

\section{Aşama 2}

Bu bölümde Yetişkin Eğitimi Analiz Ölçeği Kursiyer Formu'ndan elde edilen verilere dayalı demografik ve betimsel bulgular ele alınmaktadır.

Demografik bulgular: Demografik bulgular cinsiyet bağlamında incelendiğinde örneklem grubu içerisinde kadınların \%69,3 ile yoğunlukta olduğu gözlenmektedir. Eğitim durumu bağlamında; \%37,4 ile lise mezunlarının, hemen ardından \% 36,8 ile ortaokul mezunlarının ağırlıkta olduğu görülebilir. Katılımcların \%18,8'inin önlisans-lisans, \%5'inin de ilkokul mezunu olmasının yanında yalnızca \%1,79'unun lisansüstü eğitim düzeyinde olduğu görülmektedir. Katılımcıların, ölçeğin uygulandığı tarihe dek katılmış oldukları kurs sayısı incelendiğinde; örneklemin \%53,9'unun 2 ile 4, $\% 23,1$ 'inin beş ile yedi, yüzde $14,1^{\prime}$ inin bir ve $\% 8,7^{\prime} \operatorname{sinin}$ sekiz ile on kurs arasında kursa katılmış oldukları gözlenmiştir. Örneklem profili, katılımc1- 
ların meslekleri bağlamında incelendiğinde ise; \%42,3 ile diğer mesleklere kıyasla büyük çoğunluğun ev hanımı olduğu görülmektedir. Bunun yanında \%9,2 ile öğretmenlerin, \%5,7 ile işçilerin, \%6,5 ile öğrencilerin, \%6,3 ile memur statüsünde çalışanların ve $\% 4,3$ ile işsiz durumunda olanların da örneklem içerisinde oransal ağırlı̆̆ı bulunan diğer meslek grupları olduğu ifade edilebilir.

Değişkenlere ilişkin betimsel bulgular: Araştırmada, Türkiye'de yetişkin eğitiminin politik ve stratejik özelliklerine, örgütsel yapısına ve uygulamalarına ilişkin görüşlerin; yaş, cinsiyet, deneyim, eğitim durumu, meslek gibi değişkenler bağlamında incelenmesi amaçlanmıştır.

Çalışmada çok değişkenli istatistikler kullanıldığından, öncesinden varsayımlar araştırılmıştır. Çok değişkenli istatistik için çok değişkenli Q-Q plotlara bakılmış normallik varsayımının olduğu belirlenmiştir. Ayrıca histogramlar göz önünde bulundurulduğunda normalliğin sağlandığı tespit edilmiştir. Çarpıklık ve basıklık değerleri hesaplanmıştır. Bu analizlere ilişkin değerler Tablo 4'te sunulmuştur.

Tablo 4. YEAK'a ilişkin betimsel istatistikler

\begin{tabular}{llll}
\hline Değişkenler & Politika ve strateji & Örgütsel yapı & Uygulama \\
\hline Geçerli kişi & 614 & 614 & 614 \\
Ortalama & 2.018 & 2.094 & 6.675 \\
Ss & 0.311 & -0.490 & -0.259 \\
Çarpıklkk & 0.311 & -0.490 & -0.259 \\
Basıklı & -0.262 & -0.436 & -0.027 \\
\hline
\end{tabular}

Tablo incelendiğinde çarpıklık değerlerinin 0.031 ile -0.49 ile; basıklık değerlerinin ise -0.02 ile -0.43 arasında olduğu görülmektedir. Sonuç olarak bütün veriler göz önünde bulundurulduğunda çalışmada verilerin normallik sınırları içinde olduğu söylenebilir.

Kursiyerlerin görüşlerinin bazı değişkenlere göre incelenmesine ilişkin bulgular: Bu başlık altında yaş, cinsiyet, deneyim, eğitim durumu, meslek, eğitim-iş ilişkisi ve katıldıkları kurs sayısı gibi değişkenlere ilişkin bulgulara yer verilmektedir.

Yaş: Kursiyer görüşlerinin yaşa göre değişip değişmediğini belirlemek amacı ile çoklu varyans analizi (MANOVA) kullanılmıştır. MANOVA için ge- 
rekli varsayımlar incelenmiş ve katılımcıların yeterli olduğu, kovaryansların eşit olduğu (box testi $\mathrm{p}=.76$ ) ve Wilks' Lambda testi kullanılmıştır. Ayrıca değişkenler arası korelasyonlar incelenmiş çoklu doğrusallık probleminin olmadığı görülmüştür. Araştırmada tip 1 hatayı önlemek amacı ile univarite testleri için Bonferoni protokolü işe koşulmuştur (Huck, 2012; Pallant, 2007). $P$ değeri olan 0.05 bağımlı değişken olan 3'e bölünmüs ve yeni $P$ değeri olarak çalışmada 0.017 olarak belirlenmiştir. Anlamlı sonuçların olduğu durumlarda univarite testlerinden sonra varyanslar eşit ise Tukey testi değil ise Tamhane testi kullanılmıştır. Yapılan analizde değişkenler için çok değişkenli sonucun anlamlı olmadığı tespit edilmiştir Wilk $\Lambda=0,014, F(12$, $601)=0,961, p<0,483$, çok değişkenli $n p^{2}=.0,006$. Varyans analiz sonuçları Tablo 5 'te verilmiştir.

Tablo 5.Kursiyerlerin görüşlerinin yaşa göre değiş̧imi varyans analizi sonuçlarn

\begin{tabular}{|c|c|c|c|c|c|c|c|}
\hline $\begin{array}{l}\text { Varyans } \\
\text { Kaynağı }\end{array}$ & Bağımlı Değişken & KT & Sd & KO & F & p & $\eta_{p^{2}}$ \\
\hline \multirow[t]{3}{*}{ Sabit } & Politika ve strateji & 17863,618 & 1 & 17863,618 & 4377,922 & 0,000 & 0,878 \\
\hline & Örgütsel yapı & 176261,509 & 1 & 176261,50 & 40228,788 & 0,000 & 0,985 \\
\hline & Uygulamalar & 369256,963 & 1 & 369256,96 & 8288,892 & 0,000 & 0,932 \\
\hline \multirow[t]{3}{*}{ Yaş } & Politika ve strateji & 10,803 & 4 & 2,701 & 0,662 & 0,619 & 0,004 \\
\hline & Örgütsel yapısı & 18,529 & 4 & 4,632 & 1,057 & 0,377 & 0,007 \\
\hline & Uygulama & 185,088 & 4 & 46,272 & 1,039 & 0,386 & 0,007 \\
\hline \multirow[t]{3}{*}{ Hata } & Politika ve strateji & 2484,956 & 609 & 4,080 & & & \\
\hline & Örgütsel yapı & 2668,320 & 609 & 4,381 & & & \\
\hline & Uygulama & 27129,982 & 609 & 44,548 & & & \\
\hline
\end{tabular}

Tabloda görüldüğü gibi kursiyerlerin YE'nin politik ve stratejik özelliklerine ilişkin görüş düzeyleri, YE'nin örgütsel yapısına ilişkin görüş düzeyleri, YE'nin uygulamalarına ilişkin görüş düzeyleri yaş değişkenine göre değişmemektedir.

Cinsiyet: Araştırmada, kursiyerlerin YE'nin politik ve stratejik özelliklerine, örgütsel yapısına ve uygulamalarına ilişkin görüşlerinin cinsiyete göre incelenmesi amaçlanmıştır. Bu çerçevede kursiyerlerin görüşlerinin cinsiyete göre değişip değişmediğini belirlemek amacı ile bağımsız gruplar $t$ testi uygulanmıştır. Yapılan analizlere ilişkin puan ortalamaları ve standart sapmaları ve $\mathrm{t}$ testi sonuçları Tablo $6^{\prime}$ da verilmiştir. Testlerde varyansın eşit olduğu tespit edilmiştir. 
Tablo 6. Kursiyerlerin görüşlerinin cinsiyete göre değişimi t testi sonuçlarn

\begin{tabular}{llllllllll}
\hline Değişkenler & Grup & N & Ort. & Ss & Sh & t & Sd & p & Cohen d \\
\hline Politika & Kadın & 426 & 7.052 & 2.045 & 0.099 & -2.733 & 612 & 0.006 & -0.239 \\
ve strateji & Erkek & 188 & 7.532 & 1.919 & 0.140 & & & & \\
\hline Örgütsel yapı & Kadın & 426 & 22.390 & 2.095 & 0.102 & -1.386 & 612 & 0.166 & -0.121 \\
& Erkek & 188 & 22.644 & 2.085 & 0.152 & & & & \\
\hline Uygulama & Kadın & 426 & 32.246 & 6.838 & 0.331 & -0.397 & 612 & 0.691 & -0.035 \\
& Erkek & 188 & 32.479 & 6.305 & 0.460 & & & & \\
\hline
\end{tabular}

Tabloda görüldüğü gibi cinsiyete göre YE'nin politik ve stratejik özelliklerinin düzeyleri değişmektedir. Buna göre erkeklerin politik ve stratejik özellik düzeyleri kadınlardan daha yüksek bulunmuştur. Diğer yandan örgütsel yapısı ve uygulamalar cinsiyet değişkenine göre değişmemektedir.

Eğitim durumu: Araştırmada, kursiyerlerin YE'nin politik ve stratejik özelliklerine, örgütsel yapısına ve uygulamalarına ilişkin görüşlerinin eğitim durumuna göre incelenmesi amaçlanmıştır. Bu çerçevede kursiyerlerin görüşlerinin eğitim durumuna göre değişip değişmediğini belirlemek amac1 ile çoklu varyans analizi (MANOVA) kullanılmıştır. MANOVA için gerekli varsayımlar incelenmiş ve katılımclların yeterli olduğu, kovaryansların eşit olmadığ 1 için (box testi $\mathrm{p}=.001$ ) ve Pillai's Trace testi kullanılmıştır. Ayrıca değişkenler arası korelasyonlar incelenmiş çoklu doğrusallık probleminin olmadığı görülmüştür. Araştırmada tip 1 hatayı önlemek amacı ile univarite testleri için Bonferoni protokolü işe koşulmuştur (Huck, 2012; Pallant, 2007). $P$ değeri olan 0.05 bağımlı değişken olan 3'e bölünmüş ve yeni $P$ değeri olarak çalışmada 0.017 olarak belirlenmiştir. Anlamlı sonuçların olduğu durumlarda univarite testlerinden sonra varyanslar eşit ise Tukey testi değil ise Tamhane testi kullanılmıştır. Yapılan analizde değişkenler için çok değişkenli sonucun anlamlı olmadığı tespit edilmiştir: Pillai's Trace $=0,207 ; \mathrm{F}$ $(12,601)=11,285 ; p=.001$, çok değişkenli $n p^{2}=.0,069$. Analize ilişkin sonuçlar Tablo 7 ' de verilmiştir.

Tablo 7. Eğitim durumuna göre kursiyerlerin görüşlerinin varyans analizi sonuçlar

\begin{tabular}{llllllll}
\hline $\begin{array}{l}\text { Varyans } \\
\text { Kaynağı }\end{array}$ & Bağımlı Değişken & KT & Sd & KO & F & $\mathbf{p}$ & $\mathbf{n}_{\mathbf{p}}{ }^{\mathbf{2}}$ \\
\hline Sabit & Politika ve strateji & 9016,755 & 1 & 9016,75 & 2739,64 & 0,000 & 0,818 \\
& Örgütsel yapı & 87416,409 & 1 & 87416,40 & 19997,76 & 0,000 & 0,970 \\
& Uygulama & 183681,978 & 1 & 183681,97 & 4108,05 & 0,000 & 0,871 \\
\multirow{2}{*}{ Eğitim } & Politika ve strateji & $\mathbf{4 9 1 , 4 1 0}$ & $\mathbf{4}$ & $\mathbf{1 2 2 , 8 5}$ & $\mathbf{3 7 , 3 2}$ & $\mathbf{0 , 0 0 0}$ & $\mathbf{0 , 1 9 7}$ \\
& Örgütsel yapı & 24,721 & 4 & 6,18 & $\mathbf{1}, 41$ & 0,228 & 0,009 \\
& Uygulama & 85,088 & 4 & 21,27 & 0,47 & 0,754 & 0,003
\end{tabular}




$\begin{array}{lllll}\text { Hata } & \text { Politika ve strateji } & 2004,349 & 609 & 3,29 \\ & \text { Örgütsel yapi } & 2662,127 & 609 & 4,37 \\ & \text { Uygulama } & 27229,982 & 609 & 44,71\end{array}$

Tabloda görüldügü gibi YE'nin politik ve stratejik özellikleri bağlamında $\left.(\mathrm{F} 4,609)=37,327, \mathrm{p}=.001 ; \mathrm{\eta}_{\mathrm{p}}^{2}=0,197\right)$ anlamlı bir farklılık bulunmuştur. Diğer değişkenler ise istatistiksel olarak anlamlı bulunmamıştır. YE'nin politik ve stratejik özelliklerine ilişkin farkı tespit etmek amacıyla yapılan Tukey testi sonuçları Tablo 8'de verilmektedir:

Tablo 8. Eğitim durumlarnın politik ve stratejik özelliklerinin eğitim durumuna göre değişimine ilişkin Tukey testi sonuçlan

\begin{tabular}{|c|c|c|c|c|c|}
\hline \multirow{4}{*}{$\begin{array}{l}\text { Bağımlı değişken } \\
\text { Eğitim durumları } \\
\text { ile politik ve } \\
\text { stratejik özellikler }\end{array}$} & \multicolumn{2}{|c|}{ Eğitim düzeyi } & \multirow{2}{*}{$\begin{array}{l}\text { Ort. fark1 } \\
-0,7309\end{array}$} & \multirow{2}{*}{$\begin{array}{l}\text { sh } \\
0,34746\end{array}$} & \multirow{2}{*}{$\begin{array}{l}\mathbf{p} \\
0,220\end{array}$} \\
\hline & İlkokul & Ortaokul & & & \\
\hline & & Lise & $-1,8244^{*}$ & 0,34710 & 0,000 \\
\hline & & Ön Lisans-Lisans & $-3,0100^{*}$ & 0,36680 & 0,000 \\
\hline & & Lisansüstü & $-1,8094^{*}$ & 0,63669 & 0,037 \\
\hline & Ortaokul & İlkokul & 0,7309 & 0,34746 & 0,220 \\
\hline & & Lise & $-1,0935^{*}$ & 0,16992 & 0,000 \\
\hline & & Ön Lisans-Lisans & $-2,2791^{*}$ & 0,20721 & 0,000 \\
\hline & & Lisansüstü & $-1,0784$ & 0,56015 & 0,305 \\
\hline & Lise & İlkokul & $1,8244^{*}$ & 0,34710 & 0,000 \\
\hline & & Ortaokul & $1,0935^{*}$ & 0,16992 & 0,000 \\
\hline & & Ön Lisans-Lisans & $-1,1856^{*}$ & 0,20660 & 0,000 \\
\hline & & Lisansüstü & 0,0150 & 0,55992 & 1,000 \\
\hline & Ön Lisans & İlkokul & $3,0100^{*}$ & 0,36680 & 0,000 \\
\hline & Lisans & Ortaokul & $2,2791^{*}$ & 0,20721 & 0,000 \\
\hline & & Lise & $1,1856^{*}$ & 0,20660 & 0,000 \\
\hline & & Lisansüstü & 1,2006 & 0,57234 & 0,222 \\
\hline & Lisansüstü & İlkokul & $1,8094^{*}$ & 0,63669 & 0,037 \\
\hline & & Ortaokul & 1,0784 & 0,56015 & 0,305 \\
\hline & & Lise & $-0,0150$ & 0,55992 & 1,000 \\
\hline & & Ön Lisans-Lisans & $-1,2006$ & 0,57234 & 0,222 \\
\hline
\end{tabular}

Tabloda görüldüğü gibi ilkokul mezunu kursiyerlerin YE politik ve stratejik özelliklere ilişkin görüşleri; lise, ön lisans-lisans ve lisansüstü mezunlarına göre olumsuz yönde farklılaşmaktadır.. Benzer şekilde ortaokul mezunu kursiyerlerin YE politik ve stratejik özelliklere ilişkin görüşlerinin de, lise ve ön lisans-lisans mezunlarına göre olumsuz yönde farklılaştı̆̆1 tespit edilmiştir.

İş-eğitim ilişkisi: Araştırmada, kursiyerlerin YE'nin politik ve stratejik özelliklerine, örgütsel yapısına ve uygulamalarına ilişkin görüşlerinin; yapmakta oldukları işin katıldıkları YE programı ile ilişkili olup olmama durumuna göre incelenmesi amaçlanmıştır. Bu amaçla değişkenler arası ilişkiyi belir- 
lemek amacı ile çoklu varyans analizi (MANOVA) kullanılmıştır. Manova için gerekli varsayımlar incelenmiş ve katılımcların yeterli olduğu, kovaryansların eşit olduğu (box testi $p=.20$ ) Wilks' Lambda testi kullanılmıştır. Ayrıca değişkenler arası korelasyonlar incelenmiş ve çoklu doğrusallık probleminin olmadığı görülmüştür. Araştırmada tip 1 hatayı önlemek amaC1 ile Univarite testleri için Bonferoni protokolü işe koşulmuştur (Huck, 2012; Pallant, 2007). P değeri olan 0.05 bağımlı değişken olan 3'e bölünmüş ve yeni $\mathrm{p}$ değeri olarak çalışmada 0.017 olarak belirlenmiştir. Anlamlı sonuçların olduğu durumlarda univarite testlerinden sonra varyanslar eşit ise Tukey testi, değil ise Tamhane testi kullanılmıştır. Analizde değişkenler için çok değişkenli sonucun Bonferoni protokolü sonucu anlamlı olmadığı tespit edilmiştir: Wilk $\Lambda=.0,038, F(12,601)=2,262, p<0,036$, çok değişkenli $\eta p^{2}=$. 0,011 . Varyans analizi sonuçları Tablo 9 'da verilmiştir:

Tablo 9. Yapmakta olduklan işin, katıldıklan YE program ile ilişkili olup olmama durumuna göre kursiyerlerin görüşlerinin varyans analizi sonuçlarn

\begin{tabular}{|c|c|c|c|c|c|c|c|}
\hline $\begin{array}{l}\text { Varyans } \\
\text { Kaynağı }\end{array}$ & Bağımlı Değişken & KT & Sd & KO & $\mathbf{F}$ & $\mathrm{p}$ & $\mathbf{\eta}_{\mathrm{p}}^{2}$ \\
\hline \multirow[t]{3}{*}{ Sabit } & Politika ve strateji & 6643,071 & 1 & 6643,071 & 1639,198 & 0,000 & 0,728 \\
\hline & Örgütsel yapı & 60840,627 & 1 & 60840,627 & 13984,726 & 0,000 & 0,958 \\
\hline & Uygulama & 132215,942 & 1 & 132215,942 & 2985,827 & 0,000 & 0,830 \\
\hline \multirow[t]{3}{*}{ İlişki } & Politika ve strateji & 19,600 & 2 & 9,800 & 2,418 & 0,090 & 0,008 \\
\hline & Örgütsel yapı & 28,690 & 2 & 14,345 & 3,297 & 0,038 & 0,011 \\
\hline & Uygulama & 259,267 & 2 & 129,633 & 2,928 & 0,054 & 0,009 \\
\hline \multirow[t]{3}{*}{ Hata } & Politika ve strateji & 2476,159 & 611 & 4,053 & & & \\
\hline & Örgütsel yapı & 2658,159 & 611 & 4,351 & & & \\
\hline & Uygulama & 27055,803 & 611 & 44,281 & & & \\
\hline
\end{tabular}

Tabloda görüldüğü gibi kursiyerlerin YE'nin politik ve stratejik özelliklerine ilişkin görüş düzeyleri, YE'nin örgütsel yapısına ilişkin görüş düzeyleri, YE'nin uygulamalarına ilişkin görüş düzeyleri; yapmakta oldukları işin katıldıkları YE programı ile ilişkili olmasına göre değişmemektedir.

Katıldıklar kurs sayısı: Araştırmada, kursiyerlerin YE'nin politik ve stratejik özelliklerine, örgütsel yapısına ve uygulamalarına ilişkin görüşlerinin, katıldıkları kurs sayısına göre incelenmesi amaçlanmıştır. Bu bağlamda kursiyerlerin görüşlerinin, katıldıkları kurs sayısına göre değişip değişmediğini belirlemek amacı ile çoklu varyans analizi (MANOVA) kullanılmıştır. MANOVA için gerekli varsayımlar incelenmiş ve katılımcıların yeterli olduğu, kovaryansların eşit olduğu (Box testi $\mathrm{p}=.86$ ) Wilks' Lambda testi kul- 
lanılmıştır. Ayrıca değişkenler arası korelasyonlar incelenmiş çoklu doğrusallık probleminin olmadığı görülmüştür. Araştırmada tip 1 hatayı önlemek amac ile Univarite testleri için Bonferoni protokolü işe koşulmuştur (Huck, 2012; Pallant, 2007). P değeri olan 0.05 bağımlı değişken olan 3'e bölünmüş ve yeni $\mathrm{P}$ değeri çalışmada 0.017 olarak belirlenmiştir. Anlamlı sonuçların olduğu durumlarda univarite testlerinden sonra varyanslar eşit ise Tukey testi değil ise Tamhane testi kullanılmıştır. Yapılan analizde değişkenler için çok değişkenli sonucun Bonferoni protokolü sonucu anlamlı olmadığı tespit edilmiştir: Wilk $\Lambda=0,949, F(12,601)=3,540, p<0,01$ çok değişkenli $\eta_{p}^{2}=$ 0,017 . Varyans analiz sonuçları Tablo $10^{\prime}$ da verilmiştir.

Tablo 10. Katıldıklar kurs sayısına göre kursiyerlerin; YE'nin politik ve stratejik özelliklerine, örgütsel yapısına ve uygulamalarna ilişkin görüşlerinin varyans analizi sonuçlarn

\begin{tabular}{|c|c|c|c|c|c|c|c|}
\hline $\begin{array}{l}\text { Varyans } \\
\text { Kaynağı }\end{array}$ & Bağımlı Değişken & KT & Sd & KO & $\mathbf{F}$ & $\mathrm{p}$ & $\eta_{p^{2}}$ \\
\hline \multirow[t]{3}{*}{ Sabit } & Politika ve strateji & 21033,36 & 1 & 21033,366 & 5187,589 & 0,000 & 0,895 \\
\hline & Örgütsel yapı & 198205,6 & 1 & 198205,675 & 45709,218 & 0,000 & 0,987 \\
\hline & Uygulama & 411733,9 & 1 & 411733,951 & 9395,481 & 0,000 & 0,939 \\
\hline \multirow[t]{3}{*}{ Kurssayı } & Politika ve strateji & 22,480 & 3 & 7,493 & 1,848 & 0,137 & 0,009 \\
\hline & Örgütsel yapı & 41,74 & 3 & 13,916 & 3,209 & 0,023 & 0,016 \\
\hline & Uygulama & 583,31 & 3 & 194,438 & 4,437 & 0,004 & 0,021 \\
\hline \multirow[t]{3}{*}{ Hata } & Politika ve strateji & 2473,2 & 610 & 4,055 & & & \\
\hline & Örgütsel yapı & 2645,1 & 610 & 4,336 & & & \\
\hline & Uygulama & 26731,7 & 610 & 43,823 & & & \\
\hline
\end{tabular}

Tabloda görüldüğ̈̈ gibi eğitim uygulamaları bağlamında $(F(3,610)=$ $4,437, \mathrm{p}=.004 ; \mathrm{\eta}_{\mathrm{p}}^{2}=0,021$ ) anlamlı bir farklılık bulunmuştur. Diğer değişkenler ise istatistiksel olarak anlamlı bulunmamıştır. Eğitim uygulamalarındaki farkı tespit etmek amacı ile Tukey testi yapılmış ve sonuçları Tablo 11'de verilmiştir:

Tablo 11. Eğitim uygulamalarında kurs sayısına göre değişimine ilişkin Tukey testi sonuçlar

\begin{tabular}{llllll}
\hline Bağımlı değişken & Kurs sayısı & & Ortalama fark1 & sh & p \\
\hline Eğitim & 1 & $2-4$ & 1,0481 & 0,79756 & 0,554 \\
uygulamaları & & $\mathbf{5 - 7}$ & $\mathbf{2 , 7 7 0 1}$ & $\mathbf{0 , 9 0 1 2 9}$ & $\mathbf{0 , 0 1 2}$ \\
& & $8-10$ & 2,8072 & 1,14684 & 0,069 \\
& $2-4$ & 1 & $-1,0481$ & 0,79756 & 0,554 \\
& & $\mathbf{5 - 7}$ & $\mathbf{1 , 7 2 2 1}$ & $\mathbf{0 , 6 6 4 0 8}$ & $\mathbf{0 , 0 4 8}$ \\
& $5-7$ & $8-10$ & 1,7591 & 0,97156 & 0,269 \\
& $\mathbf{1}$ & $\mathbf{- 2 , 7 7 0 1}$ & $\mathbf{0 , 9 0 1 2 9}$ & $\mathbf{0 , 0 1 2}$ \\
& & $-1,4$ & 0,66408 & 0,048 & 1,000
\end{tabular}


Tabloda görüldüğü gibi bir kez kursa katılan kursiyerlerin eğitim uygulamalarına ilişkin düzeyleri 5-7 arası kurs alanlardan daha yüksektir. Benzer şekilde 2-4 arası kursa katılanların eğitim uygulamalarına ilişkin düzeylerinin, 5-7 arası kurs alanlardan daha yüksek olduğu görülmektedir.

YEAK'dan elde edilen verilerin analizi sonucunda ulaşlan bulgular genel olarak değerlendirildiğinde kursiyerlerin görüşlerinin yaş, cinsiyet, yapmakta oldukları iş boyutlarında değişkenlik göstermediği; buna karşılık eğitim düzeyi ve katıldıkları kurs sayısı arttıkça görüşlerin olumsuz olarak farklılaştığı görülmektedir.

\section{Sonuç ve Tartışma}

Araştırma sonucunda birinci aşamada "Yetişkin Eğitimi Analiz Ölçeği Kursiyer Formu" geliştirilmiştir. Yetişkin Eğitimi Analiz Ölçeği Kursiyer Formu'nun geliştirilmesinde 36 madde ile analize başlanmış ancak; teorik olarak anlamlı, toplam varyansın \% 47,32'ni açıklayan, 17 maddeli ve öz değerleri 1.00'in üzerinde olan 3 faktörlü 17 maddeli bir ölçek ortaya konulmuştur.

Açımlayıcı faktör analizi sonucunda örgütsel yapı boyutunun varyansın yüzde 10.86 'sinı, uygulama boyutunun $26.2^{\prime}$ sini, ve son olarak politik ve stratejik boyutun ise varyansın yüzde 10.26 'sını açıkladığı sonucuna ulaşımıştır. Ölçek maddelerinin faktör yükleri .44 ile .88 arasında bulunmaktadır.

Doğrulayıcı faktör analizleri sonucunda Ki-kare (405) serbestlik derecesi (115) oranı (X²/df) 3.5; Karşılaştırmalı Uyum İndeksi (CFI) .93; Tucker Lewis Indeksi TLI .92; Normlaştırılmamış Uyum İndeksini (NNFI) .92; Bollen Uyum İndeksinin (IFI) .93; Tahmin Hatalarının Ortalamasının Karekökü (RMSEA) .06; Standartlaştırılmış Hata Kareleri Ortalamasının Karekökü (SRMR) .05 ve İyilik Uyum İndeksi (GFI) 92 olarak tespit edilmiştir. Bu bulgulara göre ölçeğin iyi uyum değerlerine sahip olduğu söylenebilir

Güvenirlik analizleri sonucunda genel ölçeğin McDonald Omega değeri .85 Cronbach Alfa değeri .84 olarak tespit edilmiştir. Alt boyutlar için de; örgütsel yapı için McDonald Omega değeri .74 ve Cronbach Alfa değeri .74, uygulama boyutu için McDonald Omega değeri .88 ve Cronbach Alfa değe- 
ri .88 ve son olarak politik ve stratejik boyut için McDonald Omega değeri .79 ve Cronbach Alfa değeri .70 olarak tespit edilmiştir. Elde edilen bu bulgular sonucunda ölçeğin güvenilir olduğu sonucuna ulaşılmıştır.

Araştırmanın ikinci aşaması olan "Kursiyer görüşlerinin bazı değişkenlere göre incelenmesi" boyutunda veriler, demografik bulgular bağlamında değerlendirildiğinde; katılımcıların \%69,3 oranında kadınlardan oluş̧uğu sonucuna ulaşılmıştır. Bu sonuç, Miser, Ural ve Ünlühisarcıklı (2013) tarafından yapılan çalışmanın "YE katılımcılarının çoğunluğunun erkeklerden oluştuğu" yönündeki sonuçlariyla örtüşmemektedir. Bunun nedeni ise; Türkiye ortalamasıyla karşılaştırıldığında, Eskişehir ili merkez ilçelerinde kadınların YE kurumlarına erişim, ulaşım, güvenlik ve toplumsal cinsiyet eşitliği bağlamında görece katılımı kolaylaştırıcı bir toplumsal arka plana sahip olmasıyla açıklanabilmektedir. Katılımcı profili eğitim durumu bağlamında değerlendirildiğinde katılımcıların 37,4 oran ile en çok lise mezunu oldukları sonucuna ulaşılmıştır. Meslek bağlamında incelendiğinde \%42,3 ile diğer mesleklere kıyasla katılımcların büyük çoğunluğun ev hanımı olduğu; bununla birlikte katılımcların \%53,9'unun 2 ile 4 kurs arasında kursa katılmış oldukları sonuçlarına ulaşılmıştır.

Kursiyeler boyutunda değişkenlere ilişkin betimsel bulgular değerlendirildiğinde kursiyerlerin politik ve stratejik özelliklere, örgütsel yapıya ve uygulamalara ilişkin görüş düzeyleri; yaşa ve yapmakta oldukları işin katıldıkları YE programı ile ilişkili olup olmamasına göre anlamlı bir farklılık göstermemektedir. Cinsiyete göre erkeklerin politik ve stratejik özellik düzeyleri kadınlardan daha yüksek bulunmuştur. Diğer yandan örgütsel yapısı ve uygulamalar cinsiyet değişkenine göre değişmemektedir.

Ağcihan (2015) tarafından yapılan araştırmada erkeklerin kadınlara göre kursu bitirdikten sonra ekonomik hayata daha fazla katıldıkları ve kadın kursiyerlerin erkek kursiyerlere göre "atıldığım kurs hayatıma anlam kazandırmıştır" ifadesini daha fazla belirttiği yönünde bulgulara ulaşılmıştır. Bu bağlamda çalışmanın cinsiyet değişkeni açısından ortaya konan sonuçlar1 Ağcihan (2015) tarafından ortaya konan sonuçlarla örtüşmemektedir. Babanlı (2018) tarafından yapılan çalışmada "kursiyerlerinin yaşam boyu öğrenme yeterlilik düzeylerinin medeni hal ve kurslara katılım süresine göre anlamlı bir farklılık göstermediği ancak; cinsiyete, yaşa, öğrenim durumu ve kurslara katılıp katılmama durumuna göre farklılık gösterdiği" yönünde bulgulara ulaşılmıştır. Bu çalışmanın yaş değişkeni bağlamındaki 
bulguları ise Babanlı (2018) tarafından ortaya konan bulguları yaş değişkeni açısından desteklememektedir. Bu çalışmanın; Ağcihan (2015) ve Babanl'’nın (2018) çalışmaları ile farklılaşmasının nedeninin, iki çalışmanın örneklem gruplarındaki sosyo-kültürel farklılaşmalar ve araştırmaların yürütültüğü sosyolojik arka planlardaki farklılıklar olduğu düşünülmektedir.

Eğitim durumu değişkeni bağlamında değerlendirildiğinde ilkokul mezunlarının politik ve stratejik düzeylerinin lise, ön lisans-lisans ve lisansüstü mezunlarından daha düşük olduğu sonucuna ulaşılmıştır.

Kursiyerlerin katıldıkları kurs sayısı değişkeni bağlamındaki bulgular değerlendirildiğinde; 1 kez kursa katılan kursiyerlerin eğitim uygulamalar1na ilişkin düzeyleri 5-7 arası kurs alanlardan daha yüksek olduğu ve benzer şekilde 2-4 arası kursa katılanların eğitim uygulamalarına ilişkin düzeylerinin, 5-7 arası kurs alanlardan daha yüksek olduğu sonucuna ulaşılmıştır. Yani katıldıkları kurs sayısı arttıkça kursiyerlerin, eğitim uygulamalarının niteliğine ilişkin görüşleri negatif yönde değişkenlik göstermektedir.

\section{Öneriler}

Çalışmanın sonuçlarına dayanılarak, araştırmaya ve uygulamaya yönelik önerileri şu biçimde sıralamak olanaklıdır:

- Alanyazın incelendiğinde Türkiye'de YE politikalarını inceleyen s1nırlı sayıda araştırmanın olduğu görülmektedir. Bu bağlamda Türkiye'deki YE politika ve stratejilerini, örgütsel yapısını ve uygulamalarını inceleyen yeni araştırmalar yapılabilir.

- Alanyazındaki araştırmaların çoğunlukla ilişkisel tarama modelinde araştırmalar olduğu gözlenmektedir. Bu araştırmalarla birlikte, kattlımcılardan derinlemesine bilgi almaya yönelik nitel araştırmalar yapılması önerilmektedir.

- Araştırmadan elde edilen sonuca göre, kursiyerlerin katıldıkları kurs sayısı ile uygulamaların niteliğine ilişkin algıları arasında negatif yönde ilişki bulunmuştur. Bu sonucu detaylı olarak ele almaya yönelik nitel araştırma yapılması önerilmektedir.

- Bu araştırma Eskişehir ili merkez ilçelerinde yürütülmüştür. Araştırmanın farklı evrenlerde tekrar yapılarak sonuçlarının karşılaştırilması önerilmektedir. 


\section{EXTENDED ABSTRACT \\ Development of Adult Education Analysis Scale Trainee Form and Examining Trainee Views in Terms of Various Variables \\ * \\ Engin Dilbaz- Coşkun Bayrak \\ MONE-Anadolu University}

\section{Introduction}

The paradigmatic transformations in the pursuit of economic freedom, liberal effects and globalization have been the triggers of a versatile and highly accelerated change and transformation process in education in general and adult education in particular in the context of education policies. In the globalization theme, the new type of individual required by the twenty-first century is faced with increasingly diverse skills and competence areas. In this context, to prepare adult individuals for new learning, skill and competence areas; in addition, developing existing skills and competencies is a task expected from adult education. The main purpose of adult education is to educate adults in order to solve the problems of countries and societies (Park, 2002, p.286).

The main legislation guiding the adult education in Turkey, the national objectives in the context of lifelong learning and lifelong learning strategy documents; It can be said that it carries clear traces of the European Union membership process-oriented new structuring and transformations. However, there are some specific educational needs of adult education in the context of Turkey.

Indeed, when looked at the international scale participation rates and some research skills related to adult education in Turkey is primarily attract attention (OECD, 2016; OECD, 2019; Eurostat, 2019). According to data of UNHCR (2020), the number of registered refugees in Turkey has reached 4 million, and the refugee population in Turkey is more than 61 countries. It can be said that this means redefined learning needs, especially language education and literacy, for 4 million refugees. It is clear that reviews and evaluations should be made in the dimensions of de- 
termining adult education needs, setting observable-measurable goals, program and planning studies, participation barriers, RE strategies and techniques, educational environments, evaluation-monitoring and the implementation of new adult education policies.

\section{Aim}

The aim of this research is to develop the "Adult Education Analysis Scale Trainees Form" for analyzing political and strategic characteristics the organizational structure and practices of adult education in Turkey according to the views of trainees; and examine the adult education according to the views of trainees in terms of different variables. For this purpose, answers to the following questions were sought:

1. How can be demonstrated by a scale for assessing the views of the participants in adult education in Turkey?

2. Does the views of trainees on political and strategic characteristics, the organizational structure and practices of adult education in Turkey differ according to;
a) Ages
b) Gender
c) The number of courses they attended
d) Educational status
e) Profession

\section{Method}

In the first stage of the study, "Adult Education Trainees Scale Analysis Form" has been developed for analyzing political and strategic characteristics, the organizational structure and the practices of adult education in Turkey according to the views of trainees.

The second stage, which aims to examine the views of the trainees in terms of various variables, is in the relational screening model. A total of 6,242 trainees, 3,244 of them at the Odunpazar1 Public Education Center, 2,998 at the Tepebaşı Public Education Center, constitute the universe of the research. At this stage, the sample; considering easy accessibility, 
consists of 614 participants selected by stratified sampling from among the trainees attending any of the 10 most popular courses.

In the second stage of the study, the data were collected using the "Adult Education Analysis Scale Trainee Form (YEAK)". SPSS 25.0 package program was used in the analysis of the data. In the analysis of the quantitative data of the research;

1. Independent groups T-test for analysis of change by gender;

2. Multivariate Analysis of Variance (MANOVA) was applied to analyze the change according to age, experience, education status, and the job they are doing.

\section{Findings}

During the scale development phase, as of November 2017,_397 trainees were studied who have completed at least one course or are still ongoing. As a result of the analysis, a 17-item structure with three factors, which explains $47.32 \%$ of the total variance, has been revealed. The content validity of the measuring tool was provided based on expert opinions. Exploratory and confirmatory factor analyzes, and the reliability of the measuring tool and its sub-dimensions was provided according to the convenience interval of the McDonald Omega and Cronbach Alpha Reliability Coefficients._Accordingly, McDonald omega value of the general scale was determined as .85 Cronbach alpha value as .84._In order to measure the test-retest reliability, the final form of the scale was applied to 60 trainees with 21 days intervals and the correlation between them was examined. Accordingly, it was seen that the correlation between the tests was .86, that is, the test-retest reliability of the scale was ensured.

In the second phase of the study; the views on political and strategic characteristics, the organizational structure and practices of adult education in Turkey were examined in the context of variables such as ages, gender, experience, education level, profession. As a result; It was observed that the views of the trainees does not vary in terms of age, gender, job-education relationship. In the context of education status; primary school graduate trainees' views on the political and strategic aspects differentiates negatively from high school, associate degree, undergrad- 
uate and graduate graduates. Similarly, it has been determined that secondary school graduate trainees' views on RE political and strategic characteristics differ negatively compared to high school and associateundergraduate graduates. In the context of educational practices in terms of the number of courses attended; Trainees who attend a course once are higher than those who take courses between 5-7. Similarly, it is observed that the levels of the education practices of those who attend courses between 2-4 are higher than those who take courses between 5-7.

\section{Suggestions}

Based on the results of the study, it is possible to list the recommendations for research and application as follows:

- When looked at the literature it can be seen that there is a limited number of research on adult education policies and structures of adult education institutions in Turkey. In this context, new researches examining the policies, organizational structure and practices of adult education in Turkey can be done.

- It is observed that the studies in the literature are mostly based on the relational survey model. Along with these studies, qualitative research can be suggested to get in-depth information from the participants.

- As a result; it is recommended to repeat the research in different universes and compare the results.

\section{Kaynakça / References}

Ağcihan, E. (2015) Yetişkin eğitimi alanında eğitim veren eğitmenlerin yetişkin eğitimi alanındaki yeterlilikleri. Yayımlanmamış Yüksek Lisans Tezi. Yeditepe Üniveristesi, Eğitimi Bilimleri Enstitüsü, İstanbul.

Babanl, N. (2018). Yetişkin eğitimindeki kursiyerlerin yaşam boyu öğrenme yeterlikleri. Yayımlanmamış Yüksek Lisans Tezi. İstanbul Aydın Üniversitesi ve Yıldız Teknik Üniversitesi, Sosyal Bilimler Enstitüleri, İstanbul.

Bağcl, E. (2011). Avrupa Birliği'ne üyelik sürecinde Türkiye`de yaşam boyu eğitim politikaları. Ondokuz Mayıs Üniversitesi Eğitim Fakültesi Dergisi, 30(2), 139173. 
Balc, A. (1995). Örgütsel gelişme. Ankara: Pegem

Balc, A. (2001). Sosyal bilimlerde araştırma, yöntem, teknik ve ilkeler. Ankara: Pegem Akademi.

Başaran, İ. E. (1996). Türkiye eğitim sistemi. Ankara: Yargıcı.

Büyüköztürk, Ş., Çakmak, K. E., Akgün, E. Ö., Karadeniz, Ş. ve Demirel, F. (2010). Bilimsel araştırma yöntemleri (11. Baskı). Ankara: Pegem Akademi.

Candy, P. C. (2003). Lifelong learning and information litercy report. U.S. National Commission on Libraries and Information Science and National Forum on Information Literacy. Prague: Information Literacy Meeting of Experts.

Cohen, L., Manion, L. ve Morrison, K. (2000). Research methods in education. (5th Edition). New York: Routledge Falmer.

Costello, A. B. aand Osborne, J. (2005). Best practices in exploratory factor analysis: four recommendations for getting the most from your analysis. Practical Assessment, Research and Evaluation, 10, 1-9.

Comrey, A. L. and Lee, H. B. (1992). A first course in factor analysis (2nd Edition). New Jersey: Lawrence Erlbaum Associates.

DeVellis, R. F. (2012). Scale development: theory and applications. (3rd Edition). California: Sage.

Douglas, B. (2002). Sample size requirements for testing and estimating coefficient alpha. Journal of Educational and Behavioral Statistics, 27, 335-340.

Drucker, P. F. (1996). Yeni gerçekler. (Çev: B. Karanakçı). Ankara: Türkiye İş Bankası Kültür.

Ekiz, D. (2003). Eğitimde araştırma yöntem ve metotlarına giriş. Ankara: Anı.

Eurostat. (2019). Adult education survey. https:/lec.europa.eu/eurostat/cache/metadata/EN/trng_aes_12m0_esms.htm\# (Erişim tarihi: 23.10.2019).

Fabrigar, L. R., Wegener, D. T., MacCallum, R. C. and Strahan, E. J. (1999). Evaluating the use of exploratory factor analysis in psychological research. Psychological Methods, 4(3), 272-299.

Ford, J., MacCallum, R. and Tait, M. (1986). The application of exploratory factor analysis in applied psychology: A critical review and analysis. Personnel Psychology, 39, 291 - 314.

Goldberg, L. and Velicer, W. (2006). Principles of exploratory factor analysis. S. Struck (Ed). In Differentiating Normal and Abnormal Personality (p.209-237). New York: Springer.

Gorsuch, R. L. (1997). New procedure for extension analysis in exploratory factor analysis. Educational and Psychological Measurement, 57(5), 725-740. 
Gökçe, B. (2004). Toplumsal bilimlerde araştırma (4. Baskı). Ankara: Savaş.

Haig, B. (2005). An abductive theory of scientific method. Psychological Methods, 10(4), 371-88.

Henson, R. and Roberts, J. (2006). Use of exploratory factor analysis in published research: common errors and some comment on improved practice. Educational and Psychological Measurement, 66, 393-416.

Hovardaoğlu, S. (2000). Davranış bilimleri için araştırma teknikleri. Ankara: VE-GA.

Huck, S. W. (2012). Reading statistics and research. (6th edition). New York: Pearson.

Karasar, N. (2007). Bilimsel araştırma yöntemi: kavramlar, ilkeler, teknikler (17. Baskı). Ankara: Nobel.

Kline, R. B. (2013). Principles and practice of structural equation modeling. New York: Guilford.

McCroskey, J. C. and Young, T. J. (1979). The use and abuse of factor analysis in communication research. Human Communication Research, 5(4), 375-382.

Miser, R. (2002). Küreselleşen dünyada yetişkin eğitimi. Ankara Üniversitesi Ĕ̆itim Fakültesi Dergisi, 35(2), 55-60.

Miser, R., Ural, O. ve Ünlühisarcaklı, Ö. (2013). Adult education in Turkey. Adult Learning, 24(4), 167-174.

Norris, M. and Lecavalier, L. (2009). Evaluating the use of exploratory factor analysis in developmental disability psychological research. Journal Of Autism And Developmental Disorders, 40, 8-20.

Nunnally, J. C. and Bernstein, I. H. (1994). Psychometric theory (3rd Edition.). New York: McGrawHill.

OECD. (2019). Skills matter: Additional results from the survey of adult skills. https://read.oecd-ilibrary.org/education/skills-matter_1f029d8f-en\#page1(Erişim tarihi: 25.04.2020).

Oktay, A. (2001). 21. Yüzyılda eŏitim ve Türk eğitimi sistemi. İstanbul: Sedar.

Özdamar, K. (2004). Paket programlar ile istatiksel veri analizi-1. Eskişehir: Kaan.

Özoğlu, S. Ç. (1992). Davranış bilimlerinde anket; bilgi toplama aracının geliştirilmesi. Ankara Üniversitesi Ĕ̆itim Bilimleri Fakültesi Dergisi, 25 (2), 321-337.

Pallant, J. (2007). SPSS survival manual - A step by step guide to data analysis using SPSS for windows (3rd Edition.). Maidenhead: Open University.

Park, S. J. (2002). The change of South Korean adult education in globalization. International Journal of Lifelong Education., 21(3), 285-294.

Pett, M., Lackey, N. and Sullivan, J. (2003). Making sense of factor analysis: The use of factor analysis for instrument development in health care research. California: Sage. 
Sayılan, F. (2009). Küreselleşme ve yetişkin eğitimi. A. Yıldız ve M. Uysal (Der.).Yetişkin Ĕğitimi içinde (s.255-272). İstanbul: Kalkedon.

Tabachnick, B. G., Fidell and L. S. (2007). Using multivariate statistics (5th Edition). New York: Allyn \& Bacon.

Şencan, H. (2005). Sosyal ve davranışsal ölçümlerde güvenilirlik ve geçerlilik. Ankara: Seçkin.

Titmus, C., Buttedahl, P., Ironside, D. and Lengrand, P. (1997). Yetişkin eğitimi terimleri sözlüğü. (Çev: F. Oğuzkan). Ankara: UNESCO Uluslararası Eğitim Bürosu.

UNHCR. (2020). UNHCR Türkiye istatistikleri. http://www.unhcr.org/tr/wpcontent/uploads/sites/14/2020/09/UNHCR-Turkey-General-Fact-SheetSeptember-2020.pdf(Erişim tarihi: 27.09.2020).

\section{Kaynakça Bilgisi / Citation Information}

Dilbaz, E. ve Bayrak, C. (2021). Yetişkin Eğitimi Analiz Ölçeği Kursiyer Formu'nun geliştirilmesi ve kursiyer görüşlerinin çeşitli değişkenler açısından incelenmesi. OPUS-Uluslararası Toplum Araştırmaları Dergisi, 18(42), 5345-5377. DOI: 10.26466/opus.901823. 